\title{
Genetic relationships of Iranian endemic mint species, Mentha mozaffariani Jamzad and some other mint species revealed by ISSR markers
}

\author{
Ali Choupani, Abdolali Shojaeiyan *, Masoud Maleki \\ Faculty of Agriculture, Horticulture Department, Tarbiat Modares University, Nasr Bridge, Tehran, Iran
}

\begin{abstract}
Mint species (Mentha sp.) are important vegetables with medicinal and economic characteristics. In this study, the genetic relationships of 34 accessions of 5 mint species including Mentha spicata, Mentha longifolia, Mentha piperita, Mentha aquatica, and Mentha mozaffarianii Jamzad were evaluated using Inter-Simple Sequence Repeat (ISSR) markers, followed by the analysis of the polymerase chain reaction (PCR) products on a high-resolution acrylamide gel. ISSR primers yielded 74 clear and reproducible bands, of which 50 bands were polymorph $(65.28 \%)$, with a minimum of $7\left((\mathrm{TG})_{8} \mathrm{G}\right)$ and a maximum of $17\left((\mathrm{GA})_{8} \mathrm{YC}\right)$ bands per primer. Polymorphism information content (PIC) for each primer varied from 0.37 to 0.46 with an average of 0.41 . The marker index referred to $(\mathrm{GA})_{8} \mathrm{YC}$ primer as the most efficient compared to others. The analysis of the molecular variance (AMOVA) at the species level showed that variation within the species (75\%) exhibits greater partitioning than the variation among species (15\%). The cluster analysis performed was based on Nei's genetic distances using the unweighted pair group method with arithmetic mean (UPGMA) method. At the accession level, all 34 accessions were separated into 3 main clusters. The cluster analysis at the species level placed 3 species including $M$. aquatica, $M$. longifolia, and $M$. spicata in one common group. Based on the cluster analysis, the M. mozaffarianii Jamzad, as an Iranian species, was placed in Mentha section, closer to other species, when compared to $M$. piperita. The results indicated that ISSR markers alongside a high-resolution electrophoresis can be truly helpful in visualizing the diversity among different accessions of one species.
\end{abstract}

Key words: cluster analysis, PCoA, AMOVA, inter-simple sequence repeat, Mentha spp.

\section{Introduction}

Mint is known to be one of the plants that are consumed in the forms of fresh, dried, and decocted as the leafy vegetable, culinary spice, herbal tea, and folk remedy worldwide, especially in Iran. The two of the main volatile ingredients of essential oils in this valuable plant (McKay and Blumberg, 2006) are menthol and menthone. Regarding medicinal properties, numerous pharmacological and therapeutic effects have been reported including antimicrobial, antinociceptive and antipyretic, antioxidant, antitumor, antiallergenic, antiviral, antibacterial, and fungicidal activities (McKay and Blumberg 2006; Mikaili et al., 2013). Mentha is one of the genera of Lamiaceae family known to have commercial impor- tance and worldwide attention. The Mentha genus has been divided into sections, and Mentha is the largest and taxonomically most complex section including 5 basic Eurasian and African species (Mentha arvensis L., Mentha aquatica L., Mentha spicata L., Mentha longifolia L., and Mentha suaveolens Ehrh.) occupying 11 natural hybrids (Harley and Brighton 1977; Lawrence 2006). The number of determined-species varies from 13-18 (Bunsawat et al., 2004) to 25-30 (Kumar et al., 2015). Due to the heterozygosity of mint species, additionally increased by the cytomixis phenomenon, plentiful forms can be generated, and proportionately any diverse hybrid progeny can be available (Lawrence 2006;

\footnotetext{
* Corresponding author: Faculty of Agriculture, Horticulture Department, Tarbiat Modares University, Nasr Bridge, Tehran, Iran; e-mail: Shojaeiyan@modares.ac.ir
} 
Jedrzejczyk and Rewers 2018). Proper identification of mint germplasms in different regions of Iran should be prioritized in breeding programs due to the high genetic diversity of Mentha genus.

Comprehension of the molecular basis of the essential biological phenomena in plants is a prerequisite for conservation, management, and use of plant genetic resources. The proper recognition of genetic diversity is one of those phenomena that is the fundamental interest of the basic sciences involving aspects such as efficient management of crop genetic resources. Gregor Mendel applied phenotype-based genetic markers in his experiments in the $19^{\text {th }}$ century, so the concept of genetic markers is not a new one (Mondini et al., 2009). The molecular markers, including a wide range of DNA and biochemical markers, can reveal the diversity of organisms at the molecular level through using molecular biology techniques (Mondini et al., 2009).

Using ISSR technique (Wu et al., 2010; Ebrahimi et al., 2012; Maleki et al., 2015; Desai et al., 2015; Jedrzejczyk and Rewers 2018), many studies have been performed on the genetic diversity of different plant species over the last decade. ISSR is a PCR-based method, which is highly reproducible and polymorphic (Reddy et al., 2002). The ISSR method includes a random distribution of reproducible regions throughout the genome, with no prior knowledge on the sequences required (unlike simple sequences repeat, SSR markers), achieving more reliable and precise data than the random amplified polymorphic DNA (RAPD) technique (Reddy et al., 2002; Mondini et al., 2009; Wu et al., 2010). The ISSR technique generates efficient multi-locus markers that can be applied in the genetic diversity and phylogenetic analyses, fingerprinting, determining SSR motif frequency, genome mapping, gene tagging, marker-assisted selection, and evolutionary biology (Godwin et al., 1997; Reddy et al., 2002).

Few studies have been reported on the genetic variation in mint species worldwide especially in Iran (Khanuja et al., 2000; Shasany et al., 2005; Shelepova et al., 2017; Jedrzejczyk and Rewers 2018). Momeni and coworkers (2006), Kazemi and Hajizadeh (2012), and Taghiloofar and Anghourani (2014) evaluated the genetic diversity of 4,1 , and 2 mint species by RAPD markers in Iran, respectively, and suggested that RAPD markers are a suitable method for the evaluation of the genetic diversity of mint accessions. The genetic diversity of $3 \mathrm{mint}$ species by R-ISSR (RAPD-ISSR) and ISSR in Iran, was assessed by Rahimmalek (2011) and Zinodini and coworkers (2013), respectively. These studies revealed that the highest diversity is typically partitioned within species, with a low genetic diversity among them. In order to detect polymorphism among the tested plants, agarose gel electrophoresis has been utilized in all of the abovementioned studies, while nondenaturing polyacrylamide gel electrophoresis, which has a higher resolution when compared to the agarose gel electrophoresis, was used in this study. The main objective of this research was to determine the genetic diversity among and within mint species in Iran using the highresolution electrophoresis separation method. Moreover, the relationship between the Iranian endemic species called $M$. mozaffarianii Jamzad and 5 mint species has been evaluated.

\section{Materials and methods}

\section{Plant materials}

Plant samples were provided from a collection of mint species in the Faculty of Agriculture, Ferdowsi University of Mashhad, Mashhad, Iran, which included accessions from different regions of Iran. In November 2013, fresh leaf samples of 34 populations were collected and transferred to the horticulture laboratory of the Faculty of Agriculture, Tarbiat Modares University, Tehran, Iran. These accessions included the following 5 mint species: $M$. spicata (Spearmint), M. longifolia, M. piperata (peppermint), M. aquatic, and $M$. mozaffarianii Jamzad. All of the accessions were collected from 11 provinces (22 cities) of Iran, including Esfahan (11 accessions), Razavi Khorasan ( 7 accessions), Bushehr (3 accessions), Kohgiluyeh and Boyer-Ahmad (3 accessions), Mazandaran (3 accessions), Fars (2 accessions), North Khorasan (1 accession), South Khorasan (1 accession), Kerman (1 accession), Khuzestan (1 accession), Chaharmahal-o-Bakhtiari (1 accession) (Table 1, Fig. 1).

\section{DNA extraction}

To accelerate the drying process, fresh leaves of 5 individuals per accession were selected and transferred to sealed plastic bags containing 50-75 g of silica gel. Afterward, the CTAB modified method (Edwards et al., 1991) was used for genomic DNA extraction. One milligram of dried leaves were ground using Mixer Mill MM 400 
Table 1. Species and originality of the 34 mint accessions used in the present study

\begin{tabular}{|c|c|c|c|c|c|c|c|c|c|c|c|c|c|}
\hline No & Code & City & Province* & Species & Latitude & Longitude & NO & Code & City & Province* & Species & Latitude & Longitude \\
\hline 1 & A-SP & Najafabad & Esf & M. spicata & $32^{\circ} 50^{\prime} \mathrm{N}$ & $51^{\circ} 36^{\prime} \mathrm{E}$ & 18 & EC-SP & Ghaem Shahr & $\mathrm{Maz}$ & M. spicata & $36^{\circ} 27^{\prime} \mathrm{N}$ & $52^{\circ} 51^{\prime} \mathrm{E}$ \\
\hline 2 & B-SP & Esfahan 1 & Esf & M. spicata & $32^{\circ} 38^{\prime} \mathrm{N}$ & $51^{\circ} 39^{\prime} \mathrm{E}$ & 19 & S-AQ & Sari & $\mathrm{Maz}$ & M. aquatica & $36^{\circ} 33^{\prime} \mathrm{N}$ & $53^{\circ} 03^{\prime} \mathrm{E}$ \\
\hline 3 & L-SP & Esfahan 2 & Esf & M. spicata & $32^{\circ} 38^{\prime} \mathrm{N}$ & $51^{\circ} 39^{\prime} \mathrm{E}$ & 20 & RU-AQ & Chalus & $\mathrm{Maz}$ & M. aquatica & $36^{\circ} 39^{\prime} \mathrm{N}$ & $51^{\circ} 25^{\prime} \mathrm{E}$ \\
\hline 4 & D-SP & Kashan & Esf & M. spicata & $33^{\circ} 59^{\prime} \mathrm{N}$ & $51^{\circ} 26^{\prime} \mathrm{E}$ & 21 & E-LO & Esfahan 1 & Esf & M. longifolia & $32^{\circ} 38^{\prime} \mathrm{N}$ & $51^{\circ} 39^{\prime} \mathrm{E}$ \\
\hline 5 & F-SP & Natanz & Esf & M. spicata & $33^{\circ} 30^{\prime} \mathrm{N}$ & $51^{\circ} 54^{\prime} \mathrm{E}$ & 22 & G-LO & Esfahan 2 & Esf & M. longifolia & $32^{\circ} 38^{\prime} \mathrm{N}$ & $51^{\circ} 39^{\prime} \mathrm{E}$ \\
\hline 6 & H-SP & Shahin Shahr & Esf & M. spicata & $32^{\circ} 52^{\prime} \mathrm{N}$ & $51^{\circ} 34^{\prime} \mathrm{E}$ & 23 & QM-LO & Esfahan 3 & Esf & M. longifolia & $32^{\circ} 38^{\prime} \mathrm{N}$ & $51^{\circ} 39^{\prime} \mathrm{E}$ \\
\hline 7 & Kf-sp & Semirom & Esf & M. spicata & $31^{\circ} 24^{\prime} \mathrm{N}$ & $51^{\circ} 34^{\prime} \mathrm{E}$ & 24 & LT-LO & Semirom & Esf & M. longifolia & $31^{\circ} 24^{\prime} \mathrm{N}$ & $51^{\circ} 34^{\prime} \mathrm{E}$ \\
\hline 8 & M-SP & Bushehr 1 & Bus & M. spicata & $28^{\circ} 58^{\prime} \mathrm{N}$ & $50^{\circ} 50^{\prime} \mathrm{E}$ & 25 & FL-PIP & Mashhad & $\mathrm{R}-\mathrm{Kh}$ & M. piperita & $36^{\circ} 18^{\prime} \mathrm{N}$ & $59^{\circ} 36^{\prime} \mathrm{E}$ \\
\hline 9 & U-SP & Bushehr 2 & Bus & M. spicata & $38^{\circ} 28^{\prime} \mathrm{N}$ & $50^{\circ} 50^{\prime} \mathrm{E}$ & 26 & NY-LO & Golshahr & $\mathrm{R}-\mathrm{Kh}$ & M. longifolia & $36^{\circ} 18^{\prime} \mathrm{N}$ & $59^{\circ} 36^{\prime} \mathrm{E}$ \\
\hline 10 & WP-SP & Borazjan & Bus & M. spicata & $29^{\circ} 16^{\prime} \mathrm{N}$ & $51^{\circ} 13^{\prime} \mathrm{E}$ & 27 & GA-LO & Golmakan & $\mathrm{R}-\mathrm{Kh}$ & M. longifolia & $36^{\circ} 28^{\prime} \mathrm{N}$ & $59^{\circ} 09^{\prime} \mathrm{E}$ \\
\hline 11 & O-SP & Yasuj & $\mathrm{K} \& \mathrm{~B}$ & M. spicata & $30^{\circ} 40^{\prime} \mathrm{N}$ & $51^{\circ} 35^{\prime} \mathrm{E}$ & 28 & P-LO & $\begin{array}{c}\text { Torbate } \\
\text { Heydarieh }\end{array}$ & $\mathrm{R}-\mathrm{Kh}$ & M. longifolia & $35^{\circ} 24^{\prime} \mathrm{N}$ & $59^{\circ} 19^{\prime} \mathrm{E}$ \\
\hline 12 & Y-SP & Yasuj 2 & $\mathrm{~K} \& \mathrm{~B}$ & M. spicata & $30^{\circ} 40^{\prime} \mathrm{N}$ & $51^{\circ} 35^{\prime} \mathrm{E}$ & 29 & FA-LO & Faruj & $\mathrm{N}-\mathrm{Kh}$ & M. longifolia & $37^{\circ} 13^{\prime} \mathrm{N}$ & $58^{\circ} 13^{\prime} \mathrm{E}$ \\
\hline 13 & R-SP & Gonabad & $\mathrm{R}-\mathrm{Kh}$ & M. spicata & $34^{\circ} 58^{\prime} \mathrm{N}$ & $58^{\circ} 41^{\prime} \mathrm{E}$ & 30 & T-LO & Kakhk & So-Kh & M. longifolia & $32^{\circ} 34^{\prime} \mathrm{N}$ & $59^{\circ} 03^{\prime} \mathrm{E}$ \\
\hline 14 & SX-SP & Golshahr & $\mathrm{R}-\mathrm{Kh}$ & M. spicata & $36^{\circ} 18^{\prime} \mathrm{N}$ & $59^{\circ} 36^{\prime} \mathrm{E}$ & 31 & N-LO & Yasuj & $\mathrm{K} \& \mathrm{~B}$ & M. longifolia & $30^{\circ} 40^{\prime} \mathrm{N}$ & $51^{\circ} 35^{\prime} \mathrm{E}$ \\
\hline 15 & BH-SP & Mashhad & R-Kh & M. spicata & $36^{\circ} 18^{\prime} \mathrm{N}$ & $59^{\circ} 36^{\prime} \mathrm{E}$ & 32 & PZ-LO & Brujen & $\mathrm{C} \& \mathrm{~B}$ & M. longifolia & $31^{\circ} 54^{\prime} \mathrm{N}$ & $51^{\circ} 12^{\prime} \mathrm{E}$ \\
\hline 16 & J-SP & Kerman & Ker & M. spicata & $30^{\circ} 17^{\prime} \mathrm{N}$ & $57^{\circ} 05^{\prime} \mathrm{E}$ & 33 & W-LO & Kazerun & Fars & M. longifolia & $29^{\circ} 37^{\prime} \mathrm{N}$ & $51^{\circ} 39^{\prime} \mathrm{E}$ \\
\hline 17 & X-SP & Dezful & Khu & M. spicata & $32^{\circ} 22^{\prime} \mathrm{N}$ & $48^{\circ} 24^{\prime} \mathrm{E}$ & 34 & ZM-OZ & Kazerun & Fars & $\begin{array}{l}\text { M. mozaffarianii } \\
\text { Jamzad }\end{array}$ & $29^{\circ} 37^{\prime} \mathrm{N}$ & $51^{\circ} 39^{\prime} \mathrm{E}$ \\
\hline
\end{tabular}

${ }^{*}$ K\&B - Kohgiluyeh \& Boyer-Ahmad, C\&B - Chaharmahal-o-Bakhtiari, ESF - Esfahan, Bus - Bushehr, R-KH - Razavi Khorasan, N-KH - North Khorasan, S-KH - South Khorasan, Ker - Kerman, Khu - Khuzestan, Maz - Mazandaran 
Table 2. Inter-simple sequence repeat (ISSR) primers sequences and their features used in the present study

\begin{tabular}{c|c|c|c|c|c|c}
\hline ISSR & $\begin{array}{c}\text { Primer sequence } \\
{\left[5^{\prime}-3^{\prime}\right]}\end{array}$ & $\operatorname{Tm}\left[{ }^{\circ} \mathrm{C}\right]$ & $\begin{array}{c}\text { Total } \\
\text { bands }\end{array}$ & Polymorphism [\%] & PIC & MI \\
\hline 1 & $(\mathrm{TG})_{8} \mathrm{G}$ & 30.5 & 7 & 57 & 0.39 & 1.57 \\
\hline 2 & $(\mathrm{AG})_{8} \mathrm{~T}$ & 50 & 8 & 62 & 0.46 & 2.33 \\
\hline 3 & $(\mathrm{GA})_{8} \mathrm{YC}$ & 53.9 & 17 & 70 & 0.37 & 4.48 \\
\hline 4 & $(\mathrm{AC})_{8} \mathrm{YG}$ & 53.9 & 10 & 60 & 0.37 & 2.23 \\
\hline 5 & $(\mathrm{GATA})_{2}(\mathrm{GACA})_{2}$ & 44 & 12 & 83 & 0.39 & 3.96 \\
\hline 6 & $\mathrm{BDB}(\mathrm{ACA})_{5}$ & 46.1 & 8 & 50 & 0.45 & 1.88 \\
\hline 7 & $(\mathrm{GA})_{8} \mathrm{~A}$ & 50 & 12 & 75 & 0.41 & 4.09 \\
\hline Mean & & & 10.57 & 65.28 & 0.41 & 2.93 \\
\hline
\end{tabular}

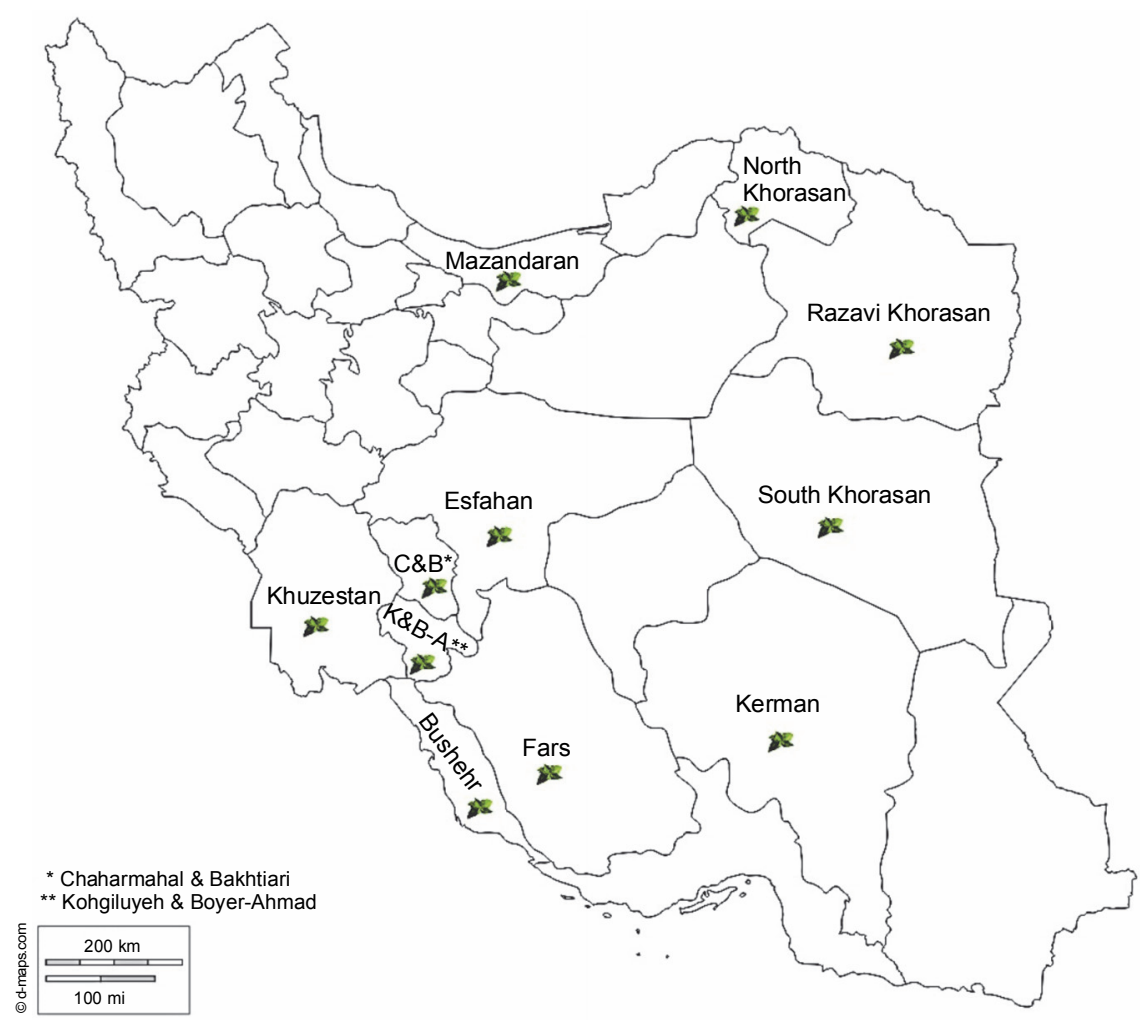

Fig. 1. Distribution of studied mint accessions throughout Iran (shown with a Mint-leaf badge)

$\mathrm{RETSCH}^{\circledR}$ and the DNA samples were diluted to $10 \mathrm{ng} / \mu \mathrm{l}$. The quality and quantity of the extracted DNA was determined using a spectrophotometer (Epoch Microplate Spectrophotometer, Biotek, USA) followed by electrophoresis in an agarose gel.

\section{ISSR amplification}

PCR mixtures contained 20 ng DNA, $0.8 \mu \mathrm{M}$ primer (Table 2), and $6.5 \mu$ l Master mix (Ampliqon, Denmark) in a total volume of $13 \mu \mathrm{l}$. The PCR of ISSR performed in a thermocycler (C 1000TM Thermal Cycler, BIORAD, USA) in the following conditions: denaturation at $95^{\circ} \mathrm{C}$ for $3 \mathrm{~min}$ followed by 34 cycles for $1 \mathrm{~min}$ of denaturation at $95^{\circ} \mathrm{C}, 1 \mathrm{~min}$ annealing at $30-54^{\circ} \mathrm{C}$ (depending on the primer), and $2 \mathrm{~min}$ of elongation at $72^{\circ} \mathrm{C}$. In addition, a final elongation was performed at $72^{\circ} \mathrm{C}$ for $10 \mathrm{~min}$. To visualize the polymorphic bands, the $\mathrm{PCR}$ products were run on $12 \%$ nondenaturing polyacrylamide gels and then 
Table 3. Analysis of molecular variance (AMOVA) 170 individuals from 34 accessions of 5 mint species using 7 inter-simple sequence repeat markers

\begin{tabular}{l|c|c|c|c|c|c}
\hline Source of variation & df & SS & MS & $\begin{array}{c}\text { Variation } \\
\text { component }\end{array}$ & $\begin{array}{c}\text { Percentage } \\
\text { of variation [\%] }\end{array}$ & $P$-value $^{\mathrm{a}}$ \\
\hline Among regions & 21 & 944.31 & 44.97 & 0.21 & 2 & \\
\hline Among accessions & 33 & 520.66 & 43.39 & 8.19 & 76 & $<0.001$ \\
\hline Within accessions & 136 & 332.20 & 2.44 & 2.44 & 23 & $<0.001$ \\
\hline Among species & 4 & 206.52 & 51.63 & 1.67 & 15 & $<0.001$ \\
\hline Within species & 165 & 1590.65 & 9.64 & 9.64 & 85 & $<0.001$ \\
\hline
\end{tabular}

a - significance tests after 1000 permutations

Table 4. Statistical measures of genetic variation as estimated by ISSR for accessions and mint species

\begin{tabular}{l|c|c|c|c}
\hline Source of variation & $\mathrm{N}$ & $\mathrm{I}$ & $\mathrm{He}$ & $\mathrm{PPL}$ \\
\hline Accessions & 34 & 0.08 & 0.05 & $14.41 \%$ \\
\hline Species & 5 & 0.30 & 0.20 & $58.10 \%$ \\
\hline
\end{tabular}

$\mathrm{N}$ - number of accessions or species; He - Nei's gene diversity; I - Shannon's information index; PPL - percentage of polymorphic loci

silver stained according to the protocol of Bassam and coworkers (1991). Inter-microsatellite band sizes were estimated comparing their migration with DNA size marker (GeneRuler 100 bp Plus DNA Ladder 100 to $3000 \mathrm{bp}$, Fermentas, USA).

\section{Data analysis}

A binary data matrix (presence (1)/absence (0)) was obtained from scoring polymorphic bands. Using the computer program GenAlex 6.501 (Peakall and Smouse 2012), Nei's (1972) genetic identity and distance among mint accessions and species were calculated. Next, using the UPGMA method based on Nei's genetic distance, clustering analyses were performed to construct a dendrogram using the SAHN-clustering cluster analysis of the NTSYS-pc 2.2 software (Rohlf 1997). Besides, to assess the partitioning of genetic variance among and within the accessions (Table 3), the AMOVA was estimated using GenAlex 6.501. The PIC for each primer was calculated as follows: $\mathrm{PIC}_{i}=2 f_{i}\left(1-f_{i}\right)$, where $\mathrm{PIC}_{i}$ is the polymorphic information content of marker " $i$ ", $f_{i}$ is the frequency of the amplified fragments (band present), and $1-f_{i}$ is the frequency of non-amplified fragments (band absent) (Table 2) (Roldàn-Ruiz et al., 2000; Grativol et al., 2011). PIC for co-dominant markers (such as SSR) ranged from 0 to 1 while it ranged from 0 to 0.5 for dominant markers (like ISSR) (De Riek et al., 2001). Furthermore, in order to determine the potential of each primer to distinguish polymorphism the marker index $(\mathrm{MI})$ was calculated using the formula $\mathrm{MI}=\mathrm{PIC} \times \eta \beta$ $(\eta$ - the number of bands; $\beta$ - the percentage of polymorphism) (Table 2) (Martos et al., 2005; Maleki et al., 2015).

The following statistical measures of variation were estimated using GenAlex 6.501 both at the accessions and species levels for the mint species: Shannon's information index (I) (Shannon and Weaver, 1959), Nei's (1972) genetic diversity (He), and percentage of polymorphic loci (PPL) (Table 4).

\section{Results and discussion}

Initially, a set of 25 ISSR primers were screened and then 7 primers that amplified clear and reproducible bands were selected for genotyping of 170 individuals from 34 accessions of the 5 mint species. Seven ISSR primers (Table 2) yielded 74 clear and reproducible bands, of which 50 bands were polymorphic (65.28\%), with a minimum of 7 (Primer 1) and a maximum of 17 (Primer 3) bands per primer. At an amplification by 
A

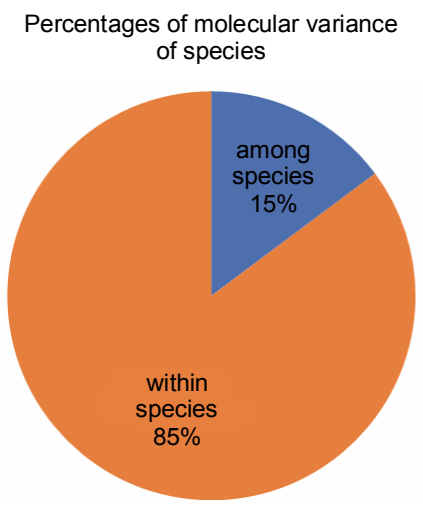

B

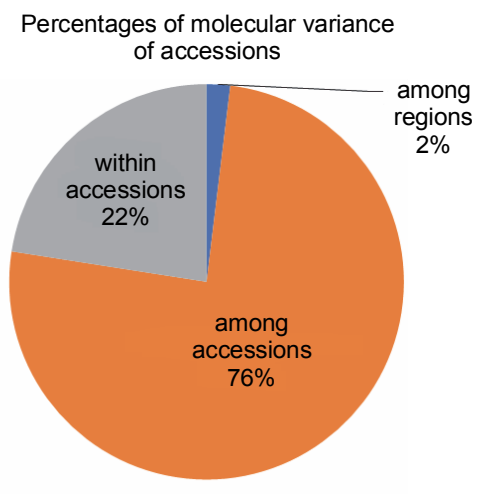

Fig. 2. Analysis of molecular variance (AMOVA) of mint accessions based on ISSR marker data at both A) 5 species and B) 34 accessions levels
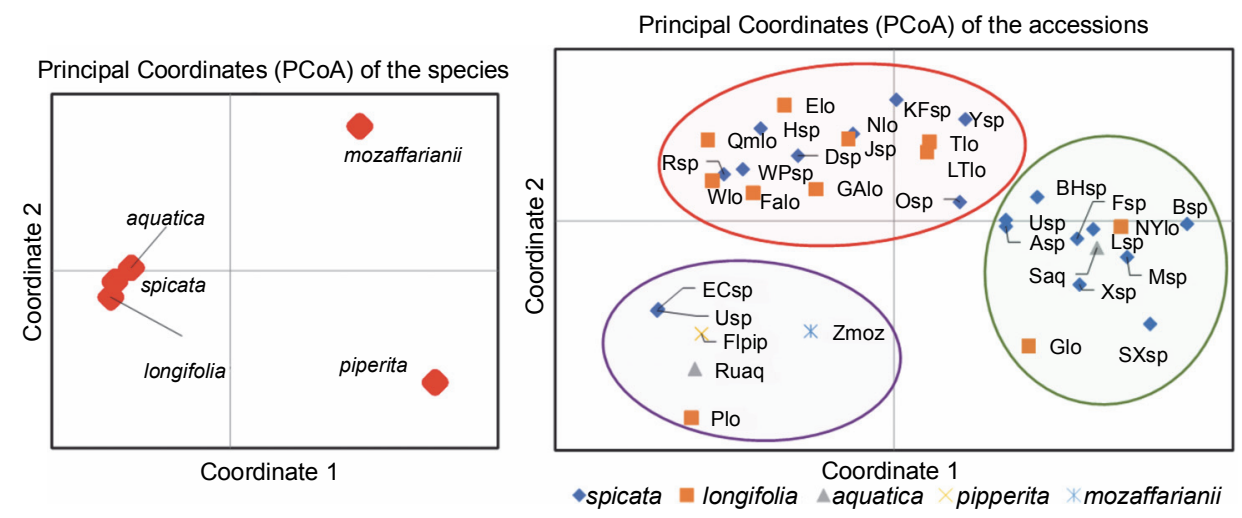

Fig. 3. Principal Coordinate Analysis $(\mathrm{PCoA})$ of 34 accessions of 5 mint species based on ISSR marker data

primer $5(83 \%)$ and primer $6(50 \%)$, respectively, the highest and lowest polymorphisms were observed. PIC for each primer varied from 0.37 to 0.46 with an average of 0.41 . The most efficient primer was primer 3 , with 4.48 value for MI, due to amplification of the highest total number of bands (Table 2).

A significant molecular variance $(P<0.001)$ was found among and within mint accessions, and also mint species. The AMOVA disclosed that the variation among and within accessions was 76 and $23 \%$, respectively. The variation among regions accounted for only $2 \%$ of the variation. These results show that the variability is higher among accessions than within them maybe because of the common artificial propagation system of mint. Conversely, the AMOVA analysis at species level showed that the variation within species $(75 \%)$ has a greater partitioning than the variation among them (15\%) (Table 3, Fig. 2). This also accords with earlier studies on mint
(Rahimmalek 2011; Zinodini et al., 2013), where the AMOVA analysis showed that a majority of the observed genetic variability was related to variation within the species.

To better visualize the relationships between mint accessions and species (Fig. 3), the principal coordinate analysis (PCoA) was separately performed on Nei's (1972) distances. PCoA results classified the accessions into 3 groups, which was further confirmed with UPGMA clustering. There was no clear distinction among accessions regarding their species. Interestingly, PCoA of 5 mint species revealed that M. spicata, M. longifolia, and $M$. aquatica species are genetically very similar, but M. mozaffarianii Jamzad and $M$. piperita species are far from each other and also from the abovementioned species. Total percentage of variation explained by the first 3 axes were 45.95 (axis $1-22.92$, axis 2 - 12.53, axis3 - 10.5) and 97.54 (axis1 - 46.55, axis2 - 37.91, axis3 
Table 5. Pairwise population matrix of Nei's unbiased genetic identity between mint species

\begin{tabular}{l|c|c|c|c|c}
\hline \multicolumn{1}{c|}{ Species } & Aquatica & Longifolia & Mozaffarianii & Piperita & Spicata \\
\hline Aquatica & 1.00 & 0.90 & 0.74 & 0.71 & 0.89 \\
\hline Longifolia & 0.90 & 1.00 & 0.72 & 0.73 & 0.97 \\
\hline Mozaffarianii & 0.74 & 0.72 & 1.00 & 0.68 & 0.74 \\
\hline Piperita & 0.71 & 0.73 & 0.68 & 1.00 & 0.72 \\
\hline Spicata & 0.89 & 0.97 & 0.74 & 0.72 & 1.00 \\
\hline
\end{tabular}

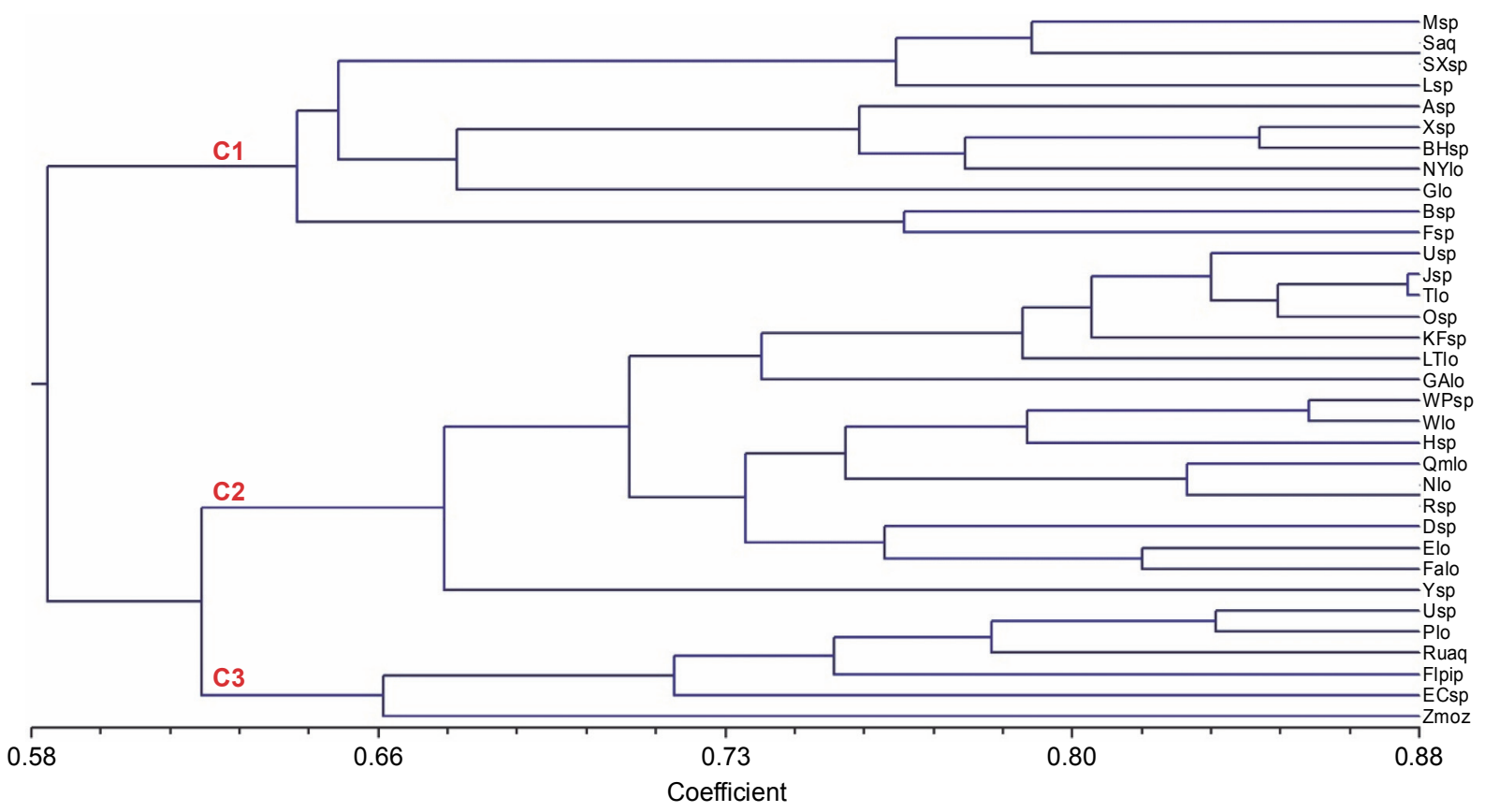

Fig. 4. UPGMA dendrogram based on Nei's genetic distance and ISSR marker data of 34 mint accessions

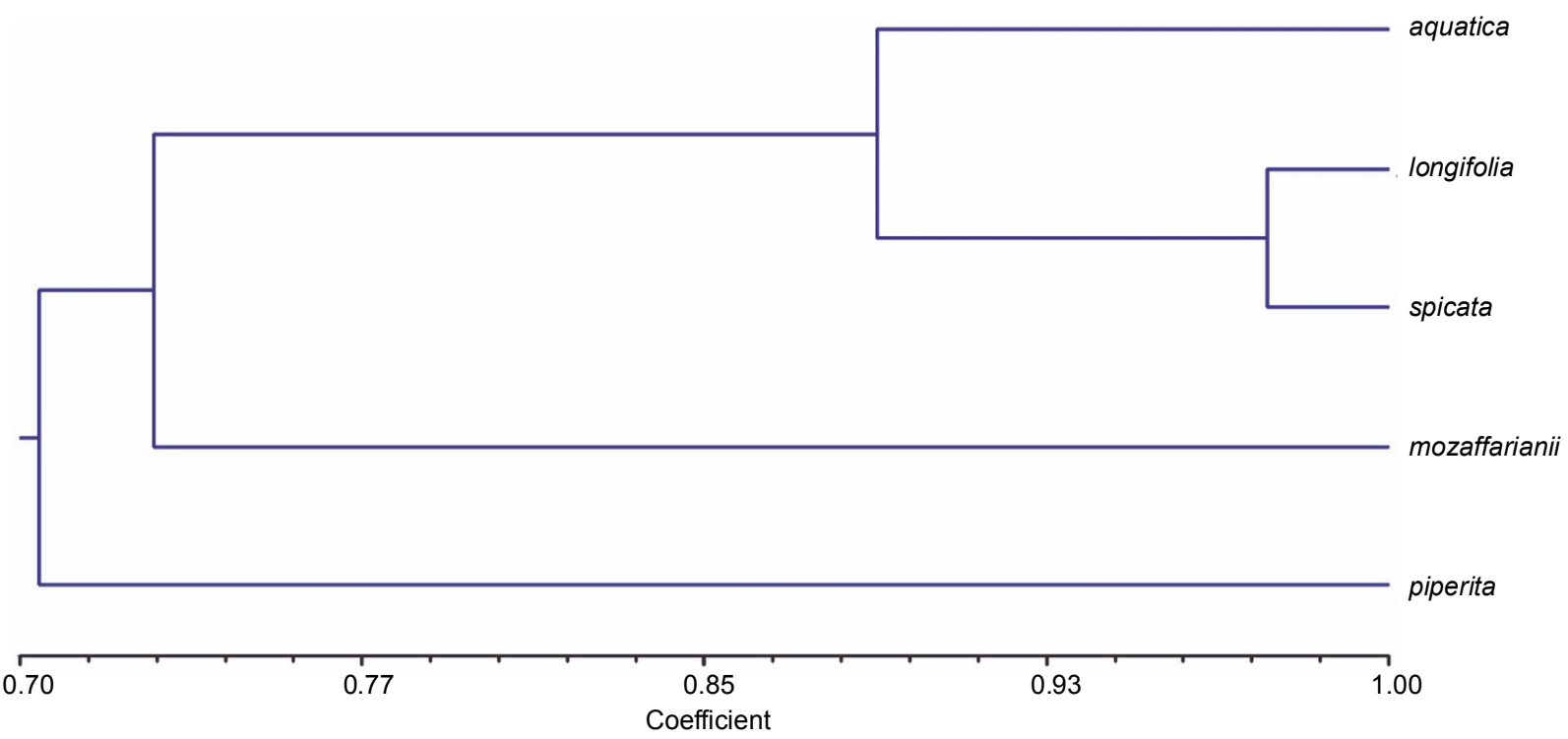

Fig. 5. UPGMA dendrogram based on Nei's genetic distance and ISSR marker data of 5 mint species 
- 13.07) for the PCoA of mint accessions and species, respectively. Zinodini and coworkers (2013) estimated $\mathrm{PCoA}$ in 3 mint species and reported that the first 3 most informative principal components described 37.3\% of the total variation in the case of ISSR markers, which was inconsistent with the results of the present study.

Table 4 presents the genetic diversity among the studied mint accession. The statistical variation measures indicated that the genetic diversity at species level was significantly high $(\mathrm{I}=0.30, \mathrm{He}=0.20, \mathrm{PPL}=58.10)$, and, in contrast, relatively low genetic diversity occurred at the level of accessions ( $\mathrm{I}=0.08, \mathrm{He}=0.05$, PPL $=14.41 \%)$ (Table 4). Zinodini and coworkers (2013) reported genetic variation for 3 mint species $(I=0.36$, $\mathrm{PPL}=66.67$ ), which was higher compared with the present study.

The maximum identity (0.97) was observed between $M$. longifolia and $M$. spicata and the minimum identity (0.68) was between $M$. piperita and $M$. mozaffarianii (Table 5) according to the pairwise population matrix of Nei's (1972) unbiased genetic identity, at the species level.

Figure 4 depicts the cluster analysis based on Nei's genetic distances using the UPGMA method. All 34 accessions were separated into 3 main clusters $(\mathrm{C} 1, \mathrm{C} 2$, and C3) at the accessions level. C1 and C2 included mostly $M$. spicata and $M$. longiflolia species according to the molecular dendrogram (Fig. 4). There was no clear distinction between these 2 species. These results were also supported by the matrix of Nei's unbiased genetic identity (0.97) and PCoA (Table 5, Fig. 3). The remaining accessions were placed in cluster $\mathrm{C} 3$, which was also confirmed by PCoA. In cluster 3 , the $Z \mathrm{moz}$ accession (which is native to Iran) was the most distant genotype, and therefore was isolated alone in the subcluster (Rustaiyan et al., 2006). This accession based on the matrix of Nei's unbiased genetic identity was genetically far from $M$. piperita (0.68), while it was close to $M$. spicata species (0.74).

The cluster analysis based on Nei's genetic distances at the species level (Fig. 5) placed $3 \mathrm{M}$. aquatica, $M$. longifolia and $M$. spicata species in a common group. The PCoA, at the species level, confirmed this result (Fig. 3). This finding is in agreement with previous studies, which reported a close relationship between M. longifolia and M. spicata (Gobert et al., 2002; Momeni et al., 2006; Kumar et al., 2015). This may be due to the fact that $M$. spicata $(2 \mathrm{n}=48)$ is a chromosomedoubled hybrid between $M$. longifolia $(2 \mathrm{n}=24)$ and M. suoveolens $(2 \mathrm{n}=24)$. The progeny of this crossing acts as a segmental allopolyploid and sometimes segregates parental characters on selfing (Harley and Brighton, 1977). Bunsawat and coworkers (2004) suggested that $M$. longiflolia is the maternal parent of $M$. spicata, rather than $M$. suoveolens. A clear separation of $M$. piperita species from others was indicated in the cluster analysis. Mentha piperita had the highest and lowest similarity with $M$. longifolia (0.73) and $M$. mozaffarianii (0.68) species, respectively. Mentha piperita is believed to be a hybrid between $M$. spicata and $M$. aquatica (Harley and Brighton, 1977); however, our results emphasize its segregation from the parents. Findings of previous studies (Khanuja et al., 2000; Momeni et al., 2006) support this result. Gobert et al. (2002) not only confirmed this result but also showed close relations of $M$. piperita with $M$. aquatica, compared to $M$. spicata species. The authors noted that two-thirds of the $M$. piperita genetic pool is constituted of the $M$. aquatica genome (Gobert et al., 2002). In the current study, 2 accessions from $M$. aquatica, which grow in Mazandaran province, were surveyed. Mentha aquatica is an octoploid species $(2 n=96)$ that are adapted to mesic conditions (Harley and Brighton, 1977). Therefore, humid and aquatic environments of Mazandaran province is very suitable for growing of this species. The Saq and Ruaq accessions of $M$. aquatica species were placed in cluster 1 (C1) and 3 (C3), respectively, which points out how much diversity exists in this species. This finding corroborates with the ideas of Kazemi and Hajizadeh (2012), who suggested that Iran is the important center of $M$. aquatica diversity and that high diversity is present in $M$. aquatica accessions in Iran. Six species and several subspecies of Mentha spp. are found in Iran, but only $M$. mozaffarianii Jamzad $(2 \mathrm{n}=2 \mathrm{x}=24)$ is exclusively native to Iran (Ghani et al., 2014). 1,8-cineole (11.1\%) and piperitone oxide isomer (43.3\%) are the primary compounds present in M. mozaffarianii Jamzad (Rustaiyan et al., 1994). The environmental conditions and the genotype highly affect the compositions of the plant (Rustaiyan et al., 2006). Based on the cluster analysis, at the species level, the M. mozaffarianii Jamzad as an Iranian species was placed in the Mentha section, genetically close to aquatica, $M$. longifolia and $M$. spicata species (Fig. 5). Besides, the cluster analysis, at the accessions level, and PCoA, at the spe- 
cies level, clearly implied on the differentiation of M. mozaffarianii Jamzad from the other species (Fig. 3 and Fig. 4). Therefore, we suggest further research to provide the true systematic position and the genetic relationship of this Iranian species with other mint species.

\section{Conclusions}

Our results indicate that ISSR markers alongside a high-resolution electrophoresis on polyacrylamide gels can be very helpful in visualizing the diversity between species and accessions, even when using a small number of primers. Iran is a big country with a miscellaneous climate, a diversity center for many crops, and the potential source for Mentha genus; so, we suggest to gather more Iranian mint genotypes and using other types of molecular markers to provide further detailed information about genetic diversity of mint accessions and species. This could lead to finding superior genotypes, in terms of essential oil yield and resistance to diseases and pests, and provide a suitable platform for the modern breeding approach of mint.

\section{Acknowledgments}

This study was supported by the University of Tarbiat Modares, Tehran, Iran.

\section{References}

Bassam B.J., Caetano-Anolles G., Gresshoff P.M (1991) Fast and sensitive silver staining of DNA in polyacrylamide gels. Anal. Biochem. 196: 80-83.

Bunsawat J., Elliott N.E., Hertweck K.L., Sproles E., Alice L.A. (2004) Phylogenetics of Mentha (Lamiaceae): Evidence from Chloroplast DNA Sequences. Syst. Bot. 29: 959-964.

De Riek J., Calsyn E., Everaert I., Van Bockstaele E., De Loose M. (2001) AFLP based alternatives for the assessment of distinctness, uniformity and stability of sugar beet varieties. Theor. Appl. Genet. 103: 1254-1265.

Desai P., Gajera B., Mankad M., Shah S., Patel A., Patil G., Narayanan S., Kumar N. (2015) Comparative assessment of genetic diversity among Indian bamboo genotypes using RAPD and ISSR markers. Mol. Biol. Rep. 42: 1265-1273.

Ebrahimi M., Farajpour M., Rahimmalek M. (2012) Inter-and intra-specific genetic diversity of Iranian yarrow species Achillea santolina and Achillea tenuifolia based on ISSR and RAPD markers. Genet. Mol. Biol. 11: 2855-2861.

Edwards K., Johnstone C., Thompson C. (1991) $A$ simple and rapid method for the preparation of plant genomic DNA for PCR analysis. Nucl. Acids Res. 19: 1349.

Ghani A., Neamati S.H., Azizi M., Saharkhiz M.J., Farsi M. (2014) Artificial autotetraploidy induction possibility of two Iranian endemic Mint. Not. Sci. Biol. 6: 185.
Gobert V., Moja S., Colson M., Taberlet P. (2002) Hybridization in the section Mentha (Lamiaceae) inferred from AFLP markers. Am. J. Bot. 89: 2017-2023.

Godwin I.D., Aitken E.A., Smith L.W. (1997) Application of inter simple sequence repeat (ISSR) markers to plant genetics. Electrophoresis 18: 1524-1528.

Grativol C., da Fonseca Lira-Medeiros C., Hemerly A.S., Ferreira P.C.G. (2011) High efficiency and reliability of intersimple sequence repeats (ISSR) markers for evaluation of genetic diversity in Brazilian cultivated Jatropha curcas $L$. accessions. Mol. Biol. Rep. 38: 4245-4256.

Harley R., Brighton C. (1977) Chromosome numbers in the genus Mentha L. Bot. J. Linn. Soc. 74: 71-96.

Jedrzejczyk I., Rewers M. (2018) Genome size and ISSR markers for Mentha L. (Lamiaceae) genetic diversity assessment and species identification. Ind. Crops Prod. 120: 171-179.

Kazemi M., Hajizadeh H.S. (2012) Assessment of genetic diversity of mints, Iranian wild "Mentha aquatica" populations using RAPD marker. J. Agric. Technol. 8: 327-336.

Khanuja S., Shasany A., Srivastava A., Kumar S. (2000) Assessment of genetic relationships in Mentha species. Euphytica 111: 121-125.

Kumar B., Kumar U., Yadav H.K. (2015) Identification of EST-SSRs and molecular diversity analysis in Mentha piperita. Crop J. 3: 335-342.

Lawrence B.M. (2006) Mint: the genus Mentha. CRC Press.

Maleki M., Shojaeiyan A., Rashidi-Monfared S. (2015) Genetic diversity analysis of Iranian melon (Cucumis melo L.) accessions using ISSR markers. Presented at: Session. V International Symposium on Cucurbits 1151; Cartagena, Murcia, Spain. 37-44.

Martos V., Royo C., Rharrabti Y., Garcia del Moral L.F. (2005) Using AFLPs to determine phylogenetic relationships and genetic erosion in durum wheat cultivars released in Italy and Spain throughout the $20^{\text {th }}$ century. Field Crops Res. 91: 107-116.

McKay D.L., Blumberg J.B. (2006) A review of the bioactivity and potential health benefits of peppermint tea (Mentha piperita L.). Phytother. Res. 20: 619-633.

Mikaili P., Mojaverrostami S., Moloudizargari M., Aghajanshakeri S. (2013) Pharmacological and therapeutic effects of Mentha Longifolia L. and its main constituent, menthol. Anc. Sci. Life 33: 131-138.

Momeni S., Shiran B., Razmjoo K. (2006) Genetic variation in Iranian mints on the bases of RAPD analysis. Pak. J. Biol. Sci. 9: 1898-1904.

Mondini L., Noorani A., Pagnotta M.A. (2009) Assessing plant genetic diversity by molecular tools. Diversity 1: 19-35.

Nei M. (1972) Genetic distance between populations. Am. Nat. 106: 283-292.

Peakall R., Smouse P. (2012) GenAlEx 6.501: genetic analysis in Excel.

Rahimmalek M. (2011) Study of genetic relationships of some mint species using R-ISSR markers. Agric. Biotechnol. 10: 11-17. 
Reddy M.P., Sarla N., Siddiq E. (2002) Inter simple sequence repeat (ISSR) polymorphism and its application in plant breeding. Euphytica 128: 9-17.

Rohlf F. (1997) NTSYS-pc 2.2. Numerical taxonomy and multivariate analysis system Exeter Software, Setauket, $N Y$.

Roldàn-Ruiz I., Dendauw J., Van Bockstaele E., Depicker A., De Loose M. (2000) AFLP markers reveal high polymorphic rates in ryegrasses (Lolium spp.). Mol. Breed. 6: 125-134.

Rustaiyan A., Jamzad M., Masoudi S., Ameri N. (2006) Volatile constituents of Nepeta heliotropifolia Lam., Mentha mozaffarianii Jamzad and Ziziphora persica Bunge. Three Labiatae herbs growing wild in Iran. J. Essent. Oil Res. 18: 348-351.

Rustaiyan A., Saberi M.M., Jassbi A.R. (1994) Constituents of the essential oil of Mentha mozaffarianii Jamzad. J. Sch. Pharm. Tehran Univ. Med. Sci. 4: 13-25.

Shannon C.E., Weaver W. (1959) The mathematical theory of communication, Urbana.
Shasany A., Darokar M., Dhawan S., Gupta A., Gupta S., Shukla A., Patra N., Khanuja S.P. (2005) Use of RAPD and AFLP markers to identify inter-and intraspecific hybrids of Mentha. J. Hered. 96: 542-549.

Shelepova O., Semenova M., Enina O., Schanzer I. (2017) Genetic, phenotypic, and phytochemical polymorphism in Eastern European populations of Mentha arvensis L. Russ. J. Genet. 53: 59-66.

Taghiloofar A.H., Anghourani H.R. (2014) Evaluation of genetic diversity among some Iranian spearmint accessions using RAPD markers. Intl. J. Agri. Crop Sci. 7: 890.

Wu Y.G., Guo Q.S., He J.C., Lin Y.F., Luo L.J., Liu G.D. (2010) Genetic diversity analysis among and within populations of Pogostemon cablin from China with ISSR and SRAP markers. Biochem Syst. Ecol. 38: 63-72.

Zinodini A., Farshadfar M., Safari H., Moradi F., Shirvani H. (2013) Study of genetic relationships of some mint species using ISSR markers. Crop Biotechnol. 5: 11-21. 